\title{
APLIKASI UNDANG-UNDANG TENTANG INFORMASI DAN PELAYANAN PUBLIK DALAM KASUS SISTEM INFORMASI TEKNOLOGI PENGELOLAAN AIR BERSIH DAN LIMBAH CAIR
}

\author{
Komarudin* dan Satmoko Yudo** \\ *Pusat Pengkajian Kebijakan Difusi Teknologi, BPP Teknologi \\ ${ }^{* *}$ Pusat Teknologi Lingkungan, BPP Teknologi \\ JI. MH. Thamrin No. 8, Jakarta
}

\begin{abstract}
The Law of Information and Electronics Transaction, the Law of Public Information Transparency, the Law of Ombudsman of the Republic of Indonesia, and the Law of Public Services is a part of the legal system related to information and public services. These four laws should be scrutinized in terms of technology application. To create prime services in the management of clean water and waste water, it has been developed the technology information system of clean water and waste water processing (SITPABLC). SITPABLC is the information system to provide information and technology services due to supporting the implementation of these four laws.
\end{abstract}

Keywords: informasi, transaksi elektronik, informasi publik, keterbukaan informasi publik, pelayanan publik, ombudsman, dan good governance.

\section{PENDAHULUAN}

Substansi "informasi" dan "pelayanan publik" muncul pada empat UU, yaitu UU tentang Informasi dan Transaksi Elektronik (ITE), UU tentang Keterbukaan Informasi Publik (KIP), UU tentang Ombudsman Republik Indonesia, dan UU tentang Pelayanan Publik. Undang-undang ini mengamanatkan PP dan Perpres sebagai acuan pelaksanaan.

UU ITE dilahirkan atas pertimbangan globalisasi informasi, kemajuan teknologi informasi, dan upaya penggunaan dan pemanfaatan teknologi informasi secara optimal, merata dan menyebar, dalam rangka menjaga, memelihara, dan memperkokoh persatuan dan kesatuan bangsa.

UU KIP dibentuk mengingat keterbukaan informasi publik merupakan pondasi dalam membangun tata pemerintahan yang baik (good governance) yang transparan, terbuka dan partisipatoris dalam seluruh proses pengelolaan kenegaraan, termasuk seluruh proses pengelolaan sumber daya publik sejak dari proses pengambilan keputusan, sampai dengan pelaksanaan serta evaluasi. Pasal 28F UUD 1945 (amandemen kedua) menegaskan bahwa setiap orang berhak untuk berkomunikasi dan memperoleh informasi untuk mengembangkan pribadi dan lingkungan sosialnya, serta berhak untuk mencari, memperoleh, memiliki, menyimpan, mengolah, dan menyampaikan informasi dengan menggunakan segala jenis saluran yang tersedia.

UU Ombudsman $\mathrm{RI}$ dibuat mengacu pada UUD NRI 1945, UU 28/1999 tentang
Penyelenggara Negara yang Bersih dan Bebas KKN, dan UU 32/2004 tentang Pemerintahan Daerah. UU Pelayanan Publik ditetapkan untuk makin mendorong partisipasi, transparansi, dan akuntabilitas serta penciptaan pelayanan publik yang prima.

Keempat undang-undang tersebut merupakan acuan, panduan dan aturan main bagaimana informasi dan pelayanan publik diterapkan oleh setiap warga negara Indonesia baik itu perorangan, organisasi atau lembaga baik swasta maupun negara.

Permasalahan utama yang sering dihadapi oleh masyarakat pada umumnya adalah rendahnya aksesibilitas terhadap berbagai sumber produktif, termasuk informasi dan pelayanan teknologi'. Di lain pihak, berbagai hasil temuan, penelitian dan inovasi/ pengembangan di perguruan tinggi, lembaga litbang (pemerintah/swasta) ataupun LSM serta potensi kemampuannya (misalnya keahlian dan/atau fasilitas) dinilai masih belum sepenuhnya (dapat) disampaikan dengan efektif dan efisien kepada pihak-pihak yang membutuhkan.

Salah satu solusi untuk mengatasi permasalahan di atas adalah dengan memanfaatan teknologi informasi yang saat ini sudah berkembang dengan pesat.

Badan Pengkajian dan Penerapan Teknologi (BPPT) sebagai Lembaga Pemerintah Non Departemen, mempunyai tupoksi (tugas pokok dan fungsi) melaksanakan tugas pemerintahan di bidang pengkajian dan penerapan teknologi sesuai dengan ketentuan peraturan perundang-undangan yang berlaku. 
Salah satu fungsinya adalah melakukan pelayanan terhadap kegiatan instansi pemerintah dan swasta di bidang pengkajian dan penerapan teknologi dalam rangka inovasi, difusi, dan pengembangan kapasitas, serta membina alih teknologi. Sedangkan salah satu wewenangnya adalah melakukan penetapan sistem informasi di bidangnya(1).

Sistem informasi di bidang lingkungan khususnya sistem informasi teknologi pengelolaan air bersih dan limbah cair adalah salah satu sistem informasi yang ada di BPPT yang dibangun untuk memberikan informasi tentang teknologi yang berhubungan dengan pengelolaan sumberdaya air, pengolahan air bersih dan limbah cair serta untuk kebutuhan masyarakat akan informasi dan pelayanan teknologi yang telah dikaji, diterapkan dan dikembangkan selama ini.

\section{TUJUAN DAN MANFAAT}

Tujuan dari penulisan ini adalah untuk membandingkan keterkaitan dan sinergi beberapa substansi empat undang-undang yang terkait dengan informasi dan pelayanan publik dalam contoh kasus pelayanan informasi teknologi pengelolaan air bersih dan limbah cair.

\section{SUBSTANSI UU ITE, UU KIP, UU OMBUDSMAN RI, DAN UU YANLIK}

\subsection{UU Tentang Informasi dan Transaksi Elektronik (ITE) ${ }^{(6)}$}

UU 11/2008 tentang ITE berisi 13 bab dan 54 pasal. Dua puluh tiga pengertian tentang ITE terdiri atas informasi elektronik, transaksi elektronik, teknologi informasi, dokumen elektronik, sistem elektronik, penyelenggaraan sistem elektronik, jaringan sistem elektronik, agen elektronik, sertifikat elektronik, penyelenggaraan sertifikasi elektronik, lembaga sertifikasi keandalan, tanda tangan elektronik, penandatanganan, komputer, akses, kode akses, kontrak elektronik, pengirim, penerima, nama domain, orang, badan usaha, dan pemerintah. Asas pemanfaatan teknologi ITE meliputi kepastian hukum, manfaat, kehati-hatian, itikad baik, dan kebebasan memilih teknologi atau netral teknologi.

Tujuannya, mencerdaskan kehidupan bangsa dalam rangka pembangunan masyarakat informasi, mengembangkan perdagangan dan perekonomian nasional, meningkatkan efektivitas dan efisiensi pelayanan publik, memajukan pemikiran dan kemampuan penggunaan dan pemanfaatan teknologi informasi, serta memberikan rasa aman, keadilan, dan kepastian hukum bagi pengguna dan penyelenggara teknologi informasi.

Informasi elektronik adalah satu atau sekumpulan data elektronik, termasuk tetapi tidak terbatas pada tulisan, suara, gambar, peta, rancangan, foto, electronic data interchange (EDI), surat elektronik (electronic mail), telegram, teleks, telecopy atau sejenisnya, huruf, tanda, angka, kode akses, simbol, atau perforasi yang telah diolah yang memiliki arti atau dapat dipahami oleh orang yang mampu memahaminya. Transaksi elektronik adalah perbuatan hukum yang dilakukan dengan menggunakan komputer, jaringan komputer, dan/atau media elektronik lainnya.

UU ini menegakkan kepastian hukum bagi pengguna dan pemanfaat teknologi informasi. UU ITE menganut "asas yurisdiksi ekstra teritorial", asas kebebasan memilih teknologi atau netral tekologi, dengan cakupan materi, antara lain pengakuan informasi dan/atau dokumen elektronik sebagai alat bukti hukum yang sah, pengakuan atas tanda tangan elektronik, penyelenggaraan sertifikasi elektronik dan sistem elektronik, nama domain, hak kekayaan intelektual dan perlindungan hak pribadi, perbuatan yang dilarang serta ketentuan pidananya (2).

Ada sembilan Rancangan Peraturan Pemerintah yang harus dibuat, yaitu RPP tentang Lembaga Sertifikasi Keandalan (Psl 10), Tanda Tangan Elektronik (Psl 11), Penyelenggara Sertifikasi Elektronik (Psl 13), Penyelenggaraan Sistem Elektronik (Psl 16), Transaksi Elektronik (Psl 17), Penyelenggara Agen Elektronik (Psl 22), Pengelola Nama Domain (Psl 24), Lawful Interception (Psl 31), dan PP Lembaga Data Strategis (Ps| 40).

Kata-kata kunci undang-undang ini, meliputi teknologi informasi, media, dan informatika (telematika), teknologi informasi, transaksi elektronik, informasi dan transaksi elektronik (ITE) yang aman, andal, dan bertanggungjawab, kejahatan baru (cyber crime), dunia "tanpa batas" (borderless), hukum siber (cyber law), hukum teknologi informasi (law of information), hukum dunia maya (virtual world law), hukum mayantara, jaringan sistem komputer dan sistem komunikasi internet, sistem informasi, sistem perdagangan secara elektronik (electronic commerce, e-commerce), ruang siber (cyber space), wilayah hukum (yurisdiksi), asasasas pemanfaatan teknologi informasi dan transaksi elektronik, sertifikasi keandalan, tandatangan elektronik, penyelenggara (orang, badan usaha, dan/atau masyarakat), pilihan hukum (choice of law), hukum perdata internasional, forum mengadili sengketa (pengadilan, arbitrase, atau lembaga penyelesaian sengketa lainnya), asas tempat 
tinggal tergugat (the basis of presence), tempat harta benda tergugat (principle of effectiveness), personal identification number (PIN), nama domain, karya intelektual, hak cipta, paten, merek, rahasia dagang, desain industri, perlindungan data pribadi dan hak pribadi (privacy right), sistem pengamanan, intersepsi atau penyadapan, dan perbuatan hukum yang dilakukan korporasi (corporate crime).

Pasal 27 sampai dengan pasal 37 mengatur perbuatan yang dilarang, antara lain dengan sengaja dan tanpa hak mendistribusikan dan/atau mentransmisikan dan/atau membuat dapat diaksesnya informasi elektronik dan/atau dokumen elektronik yang memiliki muatan yang melanggar kesusilaan, memiliki muatan perjudian, memiliki muatan penghinaan dan/atau pencemaran nama baik, dan memiliki muatan pemerasan dan/atau pengancaman.

Penyelesaian sengketa,

peran pemerintah dan masyarakat, dan penyidikan, diatur dengan tegas dalam undang-undang ini. Sanksi yang diberikan bisa mencapai $R p 12$ miliar.

\subsection{UU Tentang Keterbukaan Informasi Publik (KIP) ${ }^{(7)}$}

Pejabat Departemen Komunikasi dan Informatika, Freddy Tolung, mengemukakan filosofi dasar UU KIP, yaitu hak memperoleh informasi merupakan hak asasi manusia yang telah dijamin dalam Pasal 28 F UUD 1945 Pasal $28 \mathrm{~F}(2)$.

UU Nomor 14 Tahun 2008 tentang KIP mengatur tentang informasi, informasi publik, badan publik, komisi informasi, sengketa informasi publik, mediasi, ajudikasi, pejabat publik, pejabat pengelola informasi dan dokumentasi, pengguna dan pemohon informasi publik. Informasi publik adalah informasi yang dihasilkan, disimpan, dikelola dan/atau dikirim/diterima oleh suatu badan publik yang berkaitan dengan penyelenggara dan penyelenggaraan negara dan/atau penyelenggara dan penyelenggaraan badan publik lainnya yang sesuai dengan undang-undang ini serta informasi lain yang berkaitan dengan kepentingan publik.

Badan Publik adalah lembaga eksekutif, legislatif, yudikatif, dan badan lain yang fungsi dan tugas pokoknya berkaitan dengan penyelenggaraan negara, yang sebagian atau seluruh dananya bersumber dari Anggaran Pendapatan dan Belanja Negara dan/atau Anggaran Pendapatan dan Belanja Daerah, atau organisasi nonpemerintah sepanjang sebagian atau seluruh dananya bersumber dari Anggaran Pendapatan dan Belanja Negara dan/atau Anggaran Pendapatan dan Belanja
Daerah, sumbangan masyarakat, dan/atau sumber luar negeri.

Mediasi merupakan penyelesaian sengketa informasi publik antara para pihak melalui bantuan mediator komisi informasi. Ajudikasi adalah proses penyelesaian sengketa informasi publik antara para pihak yang diputus oleh komisi informasi. Pejabat Publik adalah orang yang ditunjuk dan diberi tugas untuk menduduki posisi atau jabatan tertentu pada badan publik. Pengguna Informasi Publik adalah orang yang menggunakan informasi publik sebagaimana diatur dalam Undang-Undang ini. Pemohon Informasi Publik adalah warga negara dan/atau badan hukum Indonesia yang mengajukan permintaan Informasi Publik sebagaimana diatur dalam Undang-Undang ini.

Asas KIP menyebutkan, setiap informasi publik bersifat terbuka dan dapat diakses dan informasi publik yang dikecualikan bersifat ketat dan terbatas (maximum access limited exemption). Informasi Publik harus dapat diperoleh secara cepat dan tepat waktu, biaya ringan, dan cara sederhana.

Tujuan KIP, menjamin hak warga negara untuk mengetahui segala sesuatu yang berkaitan dengan kebijakan publik, mendorong partisipasi masyarakat, meningkatkan peran aktif masyarakat, mewujudkan penyelenggaraan negara yang baik, mengembangkan ilmu pengetahuan dan mencerdaskan kehidupan bangsa, dan meningkatkan pengelolaan dan pelayanan informasi di lingkungan Badan Publik.

UU ini menegaskan 1) hak dan kewajiban pemohon dan pengguna informasi publik; dan 2) hak dan kewajiban badan publik.

UU ini mengatur informasi yang wajib disediakan dan diumumkan. Informasi publik yang dapat diakses, meliputi informasi yang wajib disediakan dan diumumkan secara berkala, informasi yang wajib diumumkan secara serta merta, informasi yang wajib tersedia setiap saat, informasi publik yang wajib disediakan oleh BUMN, BUMD dan/atau badan usaha lainnya yang dimiliki oleh negara, informasi publik yang wajib disediakan oleh partai politik, informasi publik yang wajib disediakan oleh organisasi nonpemerintah. dan informasi yang diperoleh berdasarkan permintaan. Di samping itu, diatur juga informasi yang dikecualikan.

Mekanisme untuk memperoleh informasi publik meliputi pemerolehan informasi publik didasarkan pada prinsip cepat, tepat waktu, dan biaya ringan. Setiap Pemohon Informasi Publik dapat mengajukan permintaan untuk memperoleh informasi publik kepada Badan Publik secara tertulis atau tidak tertulis. Badan Publik yang bersangkutan wajib menyampaikan pemberitahuan terkait informasi publik yang diminta paling lambat 10 hari kerja. 
Undang-Undang ini mengatur pembentukan Komisi Informasi (Pusat 7 orang dan Daerah 5 orang), merupakan lembaga mandiri yang berfungsi menjalankan UndangUndang ini dan peraturan pelaksanaannya, menetapkan petunjuk teknis standar layanan informasi publik dan menyelesaikan Sengketa Informasi Publik melalui Mediasi dan/atau Ajudikasi nonlitigasi. Setiap Pemohon Informasi Publik dapat mengajukan keberatan secara tertulis kepada atasan Pejabat Pengelola Informasi dan Dokumentasi apabila tidak dipenuhinya permintaan atas informasi publik. Apabila setelah mengajukan keberatan kepada atasan Pejabat Pengelola Informasi dan Dokumentasi belum mendapatkan jawaban yang memuaskan, pemohon informasi publik dapat melakukan upaya penyelesaian sengketa informasi publik yang diajukan kepada Komisi Informasi.

Dalam undang-undang ini diatur tentang hukum acara komisi dan gugatan ke pengadilan dan kasasi. Penyelesaian sengketa informasi publik oleh Komisi Informasi dilakukan melalui proses Mediasi dan/atau Ajudikasi nonlitigasi. Dalam proses Mediasi, anggota Komisi Informasi berperan sebagai mediator. Pengajuan gugatan dilakukan melalui pengadilan tata usaha negara apabila yang digugat adalah Badan Publik negara.

Tabel 1. Jenis-jenis informasi publik

\begin{tabular}{|c|c|c|}
\hline & & \\
\hline No & Kategori Informasi & Contoh Jenis Informasi \\
\hline 1 & $\begin{array}{l}\text { Informasi yang wajib } \\
\text { disediakan dan } \\
\text { diumumkan secara } \\
\text { berkala }\end{array}$ & $\begin{array}{l}\text { - informasi yang berkaitan dengan badan publik; } \\
\text { - informasi mengenai kegiatan dan kinerja badan publik terkait; } \\
\text { - } \quad \text { informasi mengenai laporan keuangan; dan } \\
\text { - informasi lain yang diatur dalam peraturan perundang-undangan. }\end{array}$ \\
\hline 2 & $\begin{array}{l}\text { Informasi yang wajib } \\
\text { diumumkan secara } \\
\text { serta merta }\end{array}$ & - informasi yang dapat mengancam hajat hidup orang banyak dan ketertiban umum. \\
\hline 3 & $\begin{array}{l}\text { Informasi yang wajib } \\
\text { tersedia setiap saat }\end{array}$ & $\begin{array}{l}\text { - daftar seluruh informasi publik yang berada di bawah penguasaannya, tidak } \\
\text { termasuk informasi yang dikecualikan; } \\
\text { - hasil keputusan badan publik dan pertimbangannya; } \\
\text { - seluruh kebijakan yang ada berikut dokumen pendukungnya; } \\
\text { - rencana kerja proyek termasuk di dalamnya perkiraan pengeluaran tahunan badan } \\
\text { publik; } \\
\text { - perjanjian badan publik dengan pihak ketiga; } \\
\text { - informasi dan kebijakan yang disampaikan pejabat publik dalam pertemuan yang } \\
\text { terbuka untuk umum; } \\
\text { - prosedur kerja pegawai badan publik yang berkaitan dengan pelayanan masyarakat; } \\
\text { dan } \\
\text { - laporan mengenai pelayanan akses informasi publik sebagaimana diatur dalam } \\
\quad \text { undang-undang ini. }\end{array}$ \\
\hline 4 & $\begin{array}{l}\text { Informasi yang wajib } \\
\text { disediakan BUMN/ } \\
\text { BUMD dan badan } \\
\text { usaha lainnya }\end{array}$ & 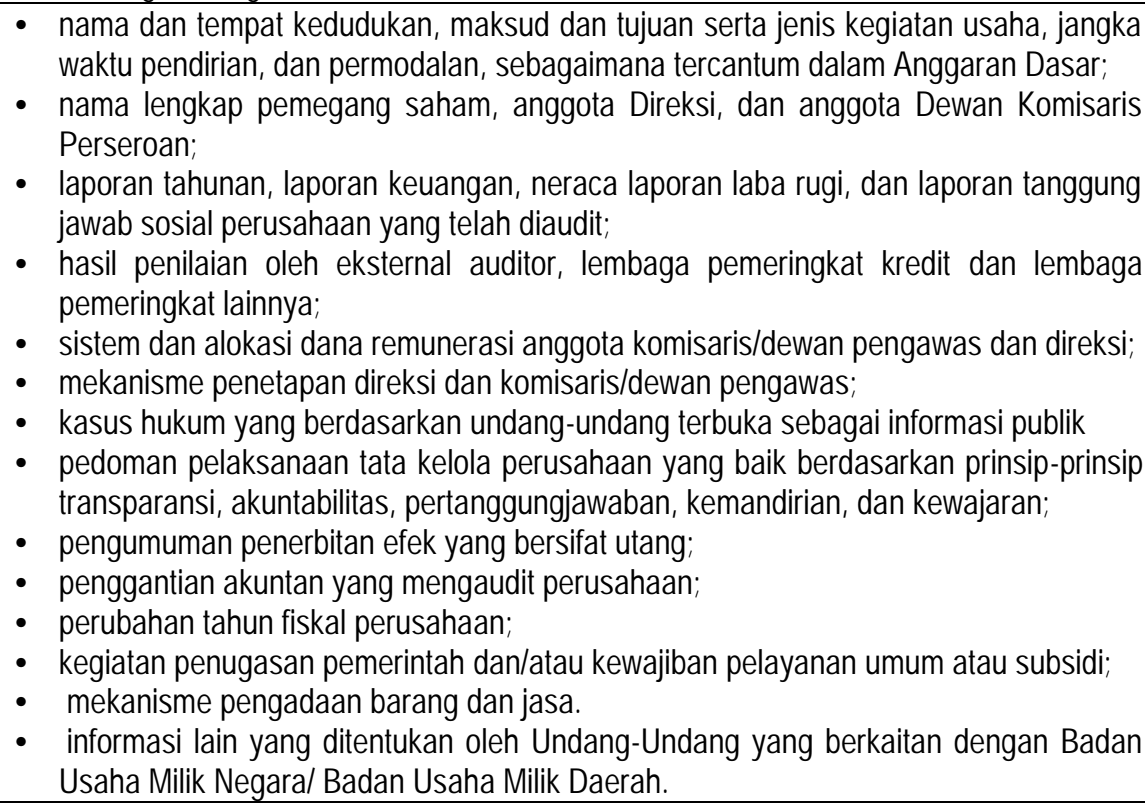 \\
\hline
\end{tabular}




\begin{tabular}{|c|c|c|}
\hline 5 & $\begin{array}{l}\text { Informasi yang wajib } \\
\text { disediakan partai } \\
\text { politik }\end{array}$ & $\begin{array}{l}\text { - } \text { asas dan tujuan; } \\
\text { - program umum dan kegiatan partai politik; } \\
\text { - nama, alamat dan susunan keengurusan dan perubahannya; } \\
\text { - pengelolaan dan penggunaan dana yanag bersumber dari anaggarana pendapatan } \\
\text { - meganisme pengambilan keputusana pendapatan dan belanja daerah; } \\
\text { - keputusan partai: hasil muktamar/kongres/munas/dan keputusan lainnya yang } \\
\text { menurut aanggaran dasar dan anggaran rumah tangga partai terbuka untuk umum; } \\
\text { dan/atau } \\
\text { - informasi lain yang ditetapkan oleh undang-undang yang berkaitan dengan partai } \\
\text { politik; }\end{array}$ \\
\hline 6 & $\begin{array}{l}\text { Informasi yang } \\
\text { wajib disediakan } \\
\text { organisasi non } \\
\text { pemerintah }\end{array}$ & 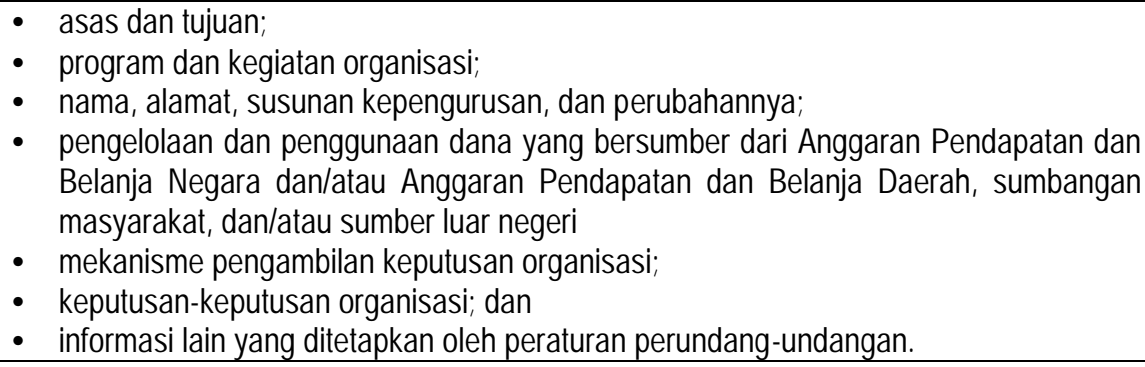 \\
\hline 7 & $\begin{array}{l}\text { Informasi yang } \\
\text { diperoleh } \\
\text { berdasarkan } \\
\text { permintaan }\end{array}$ & $\begin{array}{l}\text { - Informasi publik yang tidak tercantum dalam klasifikasi informasi yang wajib } \\
\text { disediakan dan diumumkan (secara berkala, secara serta-merta, tersedia setiap saat, } \\
\text { BUMN/BUMD, Parpol, Ornop, dan informasi yang dikecualikan). }\end{array}$ \\
\hline 8 & $\begin{array}{l}\text { Informasi yang } \\
\text { dikecualikan }\end{array}$ & $\begin{array}{l}\text { - Informasi yang apabila dibuka dapat menghambat proses penegakan hukum; } \\
\text { - Informasi yang apabila dibuka dapat mengganggu kepentingan perlindungan hak } \\
\text { - } \text { Infos kekayaan intelektual dan perlindungan dari persaingan usaha tidak sehat; } \\
\text { keamanan negara; } \\
\text { - Informasi yang apabila dibuka dapat mengungkapkan kekayaan alam Indonesia; } \\
\text { - Informasi yang apabila dibuka dapat merugikan ketahanan ekonomi nasional; } \\
\text { - informasi yang apabila dibuka dapat merugikan kepentingan hubungan luar negeri; } \\
\text { - Informasi yang apabila dibuka dapat mengungkapkan isi akta otentik yang bersifat } \\
\text { pribadi dan kemauan terakhir ataupun wasiat seseorang; } \\
\text { - Informasi yang apabila dibuka dapat mengungkap rahasia pribadi; } \\
\text { - Memorandum atau surat-surat antar badan publik atau intra badan publik, yang } \\
\text { menurut sifatnya dirahasiakan kecuali atas putusan Komisi Informasi atau } \\
\text { - } \text { Informasilan; yang tidak boleh diungkapkan berdasarkan Undang-Undang; } \\
\text { - Informasi yang dikecualikan tidak bersifat permanen; dan } \\
\text { - Ketentuan lebih lanjut mengenai jangka waktu pengecualian diatur dengan Peraturan } \\
\end{array}$ \\
\hline
\end{tabular}

\subsection{UU Tentang Ombudsman Republik Indonesia ${ }^{(8)}$}

UU Nomor 37 Tahun 2008 tentang Pelayanan Publik menegaskan bahwa pelayanan kepada masyarakat dan penegakan hukum, pengawasan pelayanan, merupakan bagian tidak terpisahkan dari upaya menciptakan pemerintahan yang baik, bersih, dan efisien. Untuk mewujudkan aparatur negara yang efektif, efisien, jujur, bersih, terbuka, dan bebas KKN, perlu dibentuk lembaga Ombudsman RI (Ombudsman).

Ombudsman Republik Indonesia yang selanjutnya disebut Ombudsman adalah lembaga negara yang mempunyai kewenangan mengawasi penyelenggaraan pelayanan publik baik yang diselenggarakan oleh penyelenggara negara dan pemerintahan termasuk yang diselenggarakan oleh Badan Usaha Milik Negara, Badan Usaha Milik Daerah, dan Badan Hukum Milik Negara serta badan swasta atau perseorangan yang diberi tugas menyelenggarakan pelayanan publik tertentu yang sebagian atau seluruh dananya bersumber dari anggaran pendapatan dan belanja negara dan/atau anggaran pendapatan dan belanja daerah. Penyelenggara Negara adalah pejabat yang menjalankan fungsi pelayanan publik yang tugas pokoknya berkaitan dengan penyelenggaraan negara sesuai dengan ketentuan peraturan perundang-undangan. 
Maladministrasi adalah perilaku atau perbuatan melawan hukum, melampaui wewenang, menggunakan wewenang untuk tujuan lain dari yang menjadi tujuan wewenang tersebut, termasuk kelalaian atau pengabaian kewajiban hukum dalam penyelenggaraan pelayanan publik yang dilakukan oleh Penyelenggara Negara dan pemerintahan yang menimbulkan kerugian materiil dan/atau immaterial bagi masyarakat dan orang perseorangan.

Tabel 2. Perbandingan Substansi UU ITE, UU KIP, UU OMBUDSMAN RI, DAN UU YANLIK

\begin{tabular}{|c|c|c|c|c|}
\hline No & UU ITE & UU KIP & UU OMBUDSMAN & UU YANLIK \\
\hline 1 & Ketentuan Umum & Ketentuan Umum & Ketentuan Umum & Ketentuan Umum \\
\hline 2 & Asas dan Tujuan & Asas dan Tujuan & Sifat, Asas, dan Tujuan & $\begin{array}{l}\text { Maksud, Tujuan, Asas, dan } \\
\text { Rglingkup }\end{array}$ \\
\hline 3 & $\begin{array}{l}\text { Informasi, Dokumen, } \\
\text { dan Tandatangan } \\
\text { Elektronik }\end{array}$ & $\begin{array}{l}\text { Hak dan Kewajiban } \\
\text { Pemohon dan Pengguna } \\
\text { Informasi Publik serta Hak } \\
\text { dan Kewajiban Badan } \\
\text { Publik }\end{array}$ & Tempat Kedudukan & $\begin{array}{l}\text { Pembina, } \\
\text { Org.Penyelenggara, dan } \\
\text { Penataan Yanlik }\end{array}$ \\
\hline 4 & $\begin{array}{l}\text { Penyelenggaraan } \\
\text { Sertifikasi Elektronik dan } \\
\text { Sistem Elektronik }\end{array}$ & $\begin{array}{l}\text { Informasi yang Wajib } \\
\text { Disediakan dan } \\
\text { diumumkan }\end{array}$ & $\begin{array}{l}\text { Fungsi, Tugas dan } \\
\text { Wewenang }\end{array}$ & $\begin{array}{l}\text { Hak, Kewajiban dan } \\
\text { Larangan }\end{array}$ \\
\hline 5 & Transaksi Elektronik & $\begin{array}{l}\text { Informasi yang } \\
\text { Dikecualikan }\end{array}$ & $\begin{array}{l}\text { Susunan dan Keanggotaan } \\
\text { Ombudsman }\end{array}$ & Penyelenggaraan Yanlik \\
\hline 6 & $\begin{array}{l}\text { Nama Domain, Hak } \\
\text { Kekayaan Intelektual, } \\
\text { dan Perlindungan } \\
\text { Hukum Pribadi }\end{array}$ & $\begin{array}{l}\text { Mekanisme Memperoleh } \\
\text { Informasi }\end{array}$ & Laporan & Peran Serta Masyarakat \\
\hline 7 & $\begin{array}{l}\text { Perbuatan yang } \\
\text { Dilarang }\end{array}$ & Komisi Informasi, & $\begin{array}{l}\text { Tata Cara Pemeriksaan } \\
\text { dan Penyelesaian Laporan }\end{array}$ & Penyelesaian Pengaduan \\
\hline 8 & Penyelesaian Sengketa & $\begin{array}{l}\text { Keberatan dan } \\
\text { Penyelesaian Sengketa } \\
\text { melalui Komisi Informasi }\end{array}$ & $\begin{array}{l}\text { Laporan Berkala dan } \\
\text { Laporan Tahunan }\end{array}$ & Ketentuan Sanksi \\
\hline 9 & $\begin{array}{l}\text { Peran Pemerintah dan } \\
\text { Peran Masyarakat }\end{array}$ & Hukum Acara Komisi & $\begin{array}{l}\text { Perwakilan Ombudsman di } \\
\text { Daerah }\end{array}$ & Ketentuan Peralihan \\
\hline 10 & Penyidikan & $\begin{array}{l}\text { Gugatan ke Pengadilan } \\
\text { dan Kasasi }\end{array}$ & Ketentuan Pidana & Ketentuan Penutup \\
\hline 11 & Ketentuan Pidana & Ketentuan Pidana & Ketentuan Peralihan & \\
\hline 12 & Ketentuan Peralihan & Ketentuan Lain-lain & Ketentuan Penutup & \\
\hline 13 & Ketentuan Penutup & Ketentuan Peralihan & & \\
\hline 14 & & Ketentuan Penutup & & \\
\hline
\end{tabular}

Laporan adalah pengaduan atau penyampaian fakta yang diselesaikan atau ditindaklanjuti oleh Ombudsman yang disampaikan secara tertulis atau lisan oleh setiap orang yang telah menjadi korban maladministrasi. Pelapor adalah warga negara Indonesia atau penduduk yang memberikan laporan kepada Ombudsman. Terlapor adalah penyelenggara negara dan pemerintahan yang melakukan maladministrasi yang dilaporkan kepada Ombudsman. Rekomendasi adalah kesimpulan, pendapat, dan saran yang disusun berdasarkan hasil investigasi Ombudsman, kepada atasan Terlapor untuk dilaksanakan dan/atau ditindaklanjuti dalam rangka peningkatan mutu penyelenggaraan administrasi pemerintahan yang baik.
Ombudsman merupakan lembaga negara yang bersifat mandiri dan tidak memiliki hubungan organik dengan lembaga negara dan instansi pemerintahan lainnya, serta dalam menjalankan tugas dan wewenangnya bebas dari campur tangan kekuasaan lainnya. Asas Ombudsman adalah kepatutan, keadilan, nondiskriminasi, tidak memihak, akuntabilitas, keseimbangan, keterbukaan, dan kerahasiaan.

Beberapa pengertian yang diatur, meliputi maladministrasi, laporan, pelapor, terlapor, dan rekomendasi. Ombudsman Republik Indonesia yang selanjutnya disebut Ombudsman adalah lembaga negara yang mempunyai kewenangan mengawasi penyelenggaraan pelayanan publik baik yang diselenggarakan oleh penyelenggara negara dan pemerintahan termasuk yang diselenggarakan 
oleh Badan Usaha Milik Negara, Badan Usaha Milik Daerah, dan Badan Hukum Milik Negara serta badan swasta atau perseorangan yang diberi tugas menyelenggarakan pelayanan publik tertentu yag sebagian atau seluruh dananya bersumber dari anggaran pendapatan dan belanja negara dan/atau anggaran pendapatan dan belanja daerah.

Ombudsman merupakan lembaga negara yang bersifat mandiri dan tidak memiliki hubungan organik dengan lembaga negara dan instansi pemerintahan lainnya, serta dalam menjalankan tugas dan wewenangnya bebas dari campur tangan kekuasaan lainnya. Ombudsman dalam menjalankan tugas dan wewenangnya berasaskan: a) kepatutan; b) keadilan; c) non-diskriminasi; d) tidak memihak; e) akuntabilitas; f) keseimbangan; g) keterbukaan; dan h) kerahasiaan.

Tujuan Ombudsman adalah 1) mewujudkan negara hukum yang demokratis, adil, dan sejahtera; 2) mendorong penyelenggaraan negara dan pemerintahan yang efektif dan efisien, jujur, terbuka, bersih, serta bebas dari korupsi, kolusi, dan nepotisme; 3) meningkatkan mutu pelayanan negara di segala bidang agar setiap warga negara dan penduduk memperoleh keadilan, rasa aman, dan kesejahteraan yang semakin baik; 4) membantu menciptakan dan meningkatkan upaya untuk pemberantasan dan pencegahan praktik-praktik maladministrasi, diskriminasi, kolusi, korupsi, dan nepotisme; dan 5) meningkatkan budaya hukum nasional, kesadaran hukum masyarakat, dan supremasi hukum yang berintikan kebenaran serta keadilan. Ombudsman berkedudukan di ibukota negara dan dapat dibentuk di pemerintah daerah.

Ombudsman berfungsi mengawasi penyelenggaraan pelayanan publik yang diselenggarakan oleh penyelenggara negara dan pemerintahan baik di pusat maupun di daerah termasuk yang diselenggarakan oleh Badan Usaha Milik Negara, Badan Usaha Milik Daerah, dan Badan Hukum Milik Negara serta badan swasta atau perseorangan yang diberi tugas menyelenggarakan pelayanan publik tertentu (Psl 6). Di samping itu diatur tugas dan wewenang Ombudsman.

Setiap Warga Negara Indonesia atau penduduk berhak menyampaikan Laporan kepada Ombudsman. Penyampaian Laporan dimaksud tidak dipungut biaya atau imbalan dalam bentuk apa pun. Undang-undang ini mengatur tata cara pemeriksaan dan penyelesaian laporan, laporan berkala dan laporan tahunan, perwakilan ombudsman di daerah, ketentuan pidana, ketentuan peralihan, dan ketentuan penutup.
Tiga PP diamanatkan UU ini, yaitu PP tentang Pembentukan, Susunan dan Tata Kerja Perwakilan Ombudsman di Daerah, PP tentang Sistem Manajemen SDM Ombudsman, dan PP tentang Hak atas Penghasilan, Uang Kehormatan, dan Hak-hak lain Ketua, Wakil Ketua, dan Anggota Ombudsman. Satu Perpres harus dibuat, yaitu Perpres tentang Susunan Organisasi, Fungsi, Tugas, Wewenang, dan Tanggungjawab Sekretariat Jenderal.

\subsection{UU Tentang Pelayanan Publik ${ }^{(9)}$}

UU Nomor 25 Tahun 2009 tentang Pelayanan Publik diharapkan dapat memberi kejelasan dan pengaturan mengenai pelayanan publik, antara lain (a) pengertian dan batasan penyelenggaraan pelayanan publik; (b) asas, tujuan, dan ruang lingkup penyelenggaraan pelayanan publik; (c) pembinaan dan penataan pelayanan publik; (d) hak, kewajiban, dan larangan bagi seluruh pihak yang terkait dalam penyelenggaraan pelayanan publik; (e) aspek penyelenggaraan pelayanan publik yang meliputi standar pelayanan, maklumat pelayanan, sistem informasi, sarana dan prasarana, biaya/tarif pelayanan, pengelolaan pengaduan, dan penilaian kinerja; (f) peran serta masyarakat; (g) penyelesaian pengaduan dalam penyelenggaraan pelayanan; dan (h) sanksi.

Ketentuan Umum, berisi pengertian tentang pelayanan publik, penyelenggara pelayanan publik, atasan satuan kerja penyelenggara, organisasi penyelenggara pelayanan publik, pelaksana pelayanan publik, masyarakat, standar pelayanan, maklumat pelayanan, sistem informasi pelayanan publik, mediasi, ajudikasi, menteri, dan ombudsman. Pelayanan publik adalah kegiatan atau rangkaian kegiatan dalam rangka pemenuhan kebutuhan pelayanan sesuai dengan peraturan perundangundangan bagi setiap warga negara dan penduduk atas barang, jasa, dan/atau pelayanan administratif yang disediakan oleh penyelenggara pelayanan publik.

Penyelenggara pelayanan publik yang selanjutnya disebut Penyelenggara adalah setiap institusi penyelenggara negara, korporasi, lembaga independen yang dibentuk berdasarkan undang-undang untuk kegiatan pelayanan publik, dan badan hukum lain yang dibentuk sematamata untuk kegiatan pelayanan publik. Organisasi Penyelenggara Pelayanan Publik yang selanjutnya disebut Organisasi Penyelenggara adalah satuan kerja penyelenggara pelayanan publik yang berada di lingkungan institusi penyelenggara, korporasi, lembaga independen yang dibentuk berdasarkan undang-undang untuk kegiatan pelayanan publik, 
dan badan hukum lain yang dibentuk sematamata untuk kegiatan pelayanan publik.

Pelaksana pelayanan publik yang selanjutnya disebut Pelaksana adalah pejabat, pegawai, petugas, dan setiap orang yang bekerja di dalam organisasi penyelenggara yang bertugas melaksanakan tindakan atau serangkaian tindakan pelayanan publik. Standar pelayanan adalah tolok ukur yang dipergunakan sebagai pedoman penyelenggaraan pelayanan dan acuan penilaian kualitas pelayanan sebagai kewajiban dan janji penyelenggara kepada masyarakat dalam rangka pelayanan yang berkualitas, cepat, mudah, terjangkau, dan terukur. Maklumat pelayanan adalah pernyataan tertulis yang berisi keseluruhan rincian kewajiban dan janji yang terdapat dalam standar pelayanan.

Mediasi adalah penyelesaian sengketa pelayanan publik antarpara pihak melalui bantuan, baik oleh ombudsman sendiri maupun melalui mediator yang dibentuk oleh ombudsman. Ajudikasi adalah proses penyelesaian sengketa pelayanan publik antarpara pihak yang diputus oleh ombudsman.

Ombudsman adalah lembaga negara yang mempunyai kewenangan mengawasi penyelenggaraan pelayanan publik sebagaimana ditetapkan dalam UU Nomor 37 Tahun 2009 tentang Ombudsman Republik Indonesia.

Undang-undang tentang pelayanan publik dimaksudkan untuk memberikan kepastian hukum dalam hubungan antara masyarakat dan penyelenggara dalam pelayanan publik. Tujuan undang-undang ini, a) terwujudnya batasan dan hubungan yang jelas tentang hak, tanggungjawab, kewajiban, dan kewenangan seluruh pihak yang terkait dengan penyelenggaraan pelayanan publik; b) terwujudnya sistem penyelenggaraan pelayanan publik yang layak sesuai dengan asas-asas umum pemerintahan dan korporasi yang baik; c) terpenuhinya penyelenggaraan pelayanan publik sesuai dengan peraturan perundang-undangan; dan d) terwujudnya perlindungan dan kepastian hukum bagi masyarakat dalam penyelenggaraan pelayanan publik.

Asas penyelenggaraan pelayanan publik adalah kepentingan umum, kepastian hukum, kesamaan hak, keseimbangan hak dan kewajiban, keprofesionalan, partisipatif, persamaan perlakuan/tidak diskriminatif, keterbukaan, akuntabilitas, fasilitas dan perlakuan khusus bagi kelompok rentan, ketepatan waktu, serta kecepatan, kemudahan, dan keterjangkauan. Ruang lingkup pelayanan publik meliputi pelayanan barang publik dan jasa publik serta pelayanan administratif yang diatur dalam peraturan perundang-undangan.
UU ini mengatur tentang pembina, organisasi penyelenggara, dan penataan pelayanan publik. Pembina terdiri atas a) pimpinan lembaga negara, pimpinan kementerian, pimpinan lembaga pemerintah nonkementerian, pimpinan lembaga komisi negara atau yang sejenis, dan pimpinan lembaga lainnya; b) gubernur pada tingkat provinsi; c) bupati pada tingkat kabupaten; dan d) walikota pada tingkat kota. Penanggungjawab adalah pimpinan kesekretariatan lembaga atau pejabat yang ditunjuk Pembina. Dalam rangka mempermudah penyelenggaraan berbagai bentuk pelayanan publik, dapat dilakukan penyelenggaraan sistem pelayanan terpadu yang diatur lebih lanjut dalam peraturan pemerintah.

Penyelenggara berkewajiban melaksanakan evaluasi terhadap kinerja pelaksana di lingkungan organisasi secara berkala dan berkelanjutan, melakukan penyeleksian dan promosi pelaksana secara transparan, tidak diskriminatif, dan adil sesuai dengan peraturan perundang-undangan, memberikan penghargaan dan sanksi. Dalam rangka meningkatkan efisiensi dan efektivitas pelayanan, dapat dilakukan kerja sama antar penyelenggara, meliputi kegiatan teknis operasional pelayanan dan/atau pendukung pelayanan dan dapat meminta bantuan kepada penyelenggara lain (dalam keadaan darurat). Penyelenggara dapat melakukan kerjasama dalam bentuk penyerahan sebagian tugas penyelenggaraan pelayanan publik kepada pihak lain yang berbadan hukum Indonesia sesuai dengan peraturan perundangundangan, sepanjang tidak menambah beban bagi masyarakat. Penyelenggara juga dapat melakukan kerjasama tertentu dengan pihak lain untuk menyelenggarakan pelayanan publik.

Hak, kewajiban, dan larangan bagi penyelenggara, kewajiban dan larangan bagi pelaksana, serta hak dan kewajiban masyarakat, juga diatur. Penyelenggara berkewajiban menyusun dan menetapkan standar pelayanan dengan memperhatikan kemampuan penyelenggara, kebutuhan masyarakat, dan kondisi lingkungan, wajib mengikutsertakan masyarakat dan pihak terkait (dengan prinsip tidak diskriminatif, terkait langsung dengan jenis pelayanan, memiliki kompetensi dan mengutamakan musyawarah, serta memperhatikan keberagaman), dan menerapkan standar pelayanan. Penyusunan standar pelayanan diatur lebih lanjut dalam peraturan pemerintah.

Komponen standar pelayanan sekurangkurangnya meliputi dasar hukum, persyaratan; sistem, mekanisme, dan prosedur; jangka waktu penyelesaian, biaya/tariff, produk pelayanan; sarana, prasarana, dan/atau fasilitas; kompetensi 
pelaksana, pengawasan internal; penanganan pengaduan, saran, dan masukan; jumlah pelaksana, jaminan pelayanan yang memberikan kepastian pelayanan dilaksanakan sesuai dengan standar pelayanan, jaminan keamanan dan keselamatan pelayanan dalam bentuk komitmen untuk memberikan rasa aman, bebas dari bahaya, dan risiko keragu-raguan; dan evaluasi kinerja pelaksana.

Penyelenggara berkewajiban menyusun dan menetapkan maklumat pelayanan, mengelola sarana, prasarana dan/atau fasilitas, menyediakan sarana pengaduan, melakukan penilaian kinerja, memberikan pelayanan dengan perlakuan khusus dan pelayanan berjenjang. Pelayanan berjenjang, harus memenuhi ketentuan tentang proporsi akses dan pelayanan kepada kelompok masyarakat berdasarkan asas persamaan perlakuan, keterbukaan, serta keterjangkauan masyarakat. Ketentuan mengenai proporsi akses dan kategori kelompok masyarakat dimaksud, diatur lebih lanjut dalam peraturan pemerintah.

Biaya/tarif pelayanan publik pada dasarnya merupakan tanggungjawab negara (dibebankan kepada negara apabila diwajibkan dalam peraturan perundang-undangan) dan/atau masyarakat (penerima pelayanan publik). Penyelenggara berhak mendapatkan alokasi anggaran sesuai dengan tingkat kebutuhan pelayanan dan penyelenggara dapat memperoleh anggaran dari pendapatan hasil pelayanan publik.

Penyelenggara harus berperilaku adil dan tidak diskriminatif, cermat, santun dan ramah; tegas, andal, dan tidak memberikan putusan yang berlarut-larut; profesional, tidak mempersulit, patuh pada perintas atasan yang sah dan wajar, menjunjung tinggi nilai-nilai akuntabilitas dan integritas institusi penyelenggara; tidak membocorkan informasi atau dokumen yang wajib dirahasiakan sesuai dengan peraturan perundang-undangan, terbuka dan menyalahgunakan sarana dan prasarana serta fasilitas pelayanan publik, tidak memberikan informasi yang salah atau menyesatkan dalam menanggapi permintaan informasi serta proaktif dalam memenuhi kepentingan masyarakat; tidak menyalahgunakan informasi, jabatan, dan/atau kewenangan yang dimiliki, sesuai dengan kepantasan dan tidak menyimpang dari prosedur.

\section{Pengawasan}

penyelenggaraan pelayanan publik dilakukan oleh pengawas internal (atasan langsung, pengawasan fungsional) dan pengawas eksternal (pengawasan oleh masyarakat, ombudsman, dan DPR dan DPRD Provinsi, dan DPRD Kabupaten/Kota). Peran serta masyarakat dalam penyelenggaraan pelayanan publik dimulai sejak penyusunan standar pelayanan sampai dengan evaluasi dan pemberian penghargaan, diwujudkan dalam bentuk kerjasama, pemenuhan hak dan kewajiban masyarakat, serta peran aktif dalam penyusunan kebijakan pelayanan publik. Masyarakat dapat membentuk lembaga penyelenggaraan pelayanan publik. Tatacara pengikutsertaan masyarakat dalam penyelenggaraan pelayanan publik diatur lebih lanjut dalam peraturan pemerintah.

Penyelesaian pengaduan, berisi pengaturan tentang pengaduan, penyelesaian pengaduan oleh Ombudsman, penyelesaian pengaduan oleh penyelenggara pelayanan publik, dan pelanggaran hukum dalam penyelenggaraan pelayanan publik. Mengenai Ombudsman, pelajari Undang-Undang Nomor 37 Tahun 2008 tentang Ombudsman Republik Indonesia. Ombudsman wajib menerima dan berwenang memproses pengaduan dari masyarakat mengenai penyelenggaraan pelayanan publik sesuai dengan undang-undang ini. Ombudsman wajib menyelesaikan pengaduan masyarakat (jika pengadu menghendaki penyelesaian pengaduan tidak dilakukan oleh penyelenggara), wajib membentuk perwakilan di daerah yang bersifat hierarkhis (paling lambat 3 tahun sejak undangundang ini diundangkan), wajib melakukan mediasi dan konsiliasi dalam menyelesaikan pengaduan atas permintaan para pihak.

$$
\text { Penyelenggara wajib memeriksa }
$$

pengaduan dari masyarakat mengenai pelayanan publik yang diselenggarakannya, berpedoman pada prinsip independen, nondiskriminasi, tidak memihak, dan tidak memungut biaya, dan wajib menjaga kerahasiaan (tidak gugur setelah pimpinan penyelenggara berhenti atau diberhentikan dari jabatannya). Dalam menyelesaikan ganti rugi, ombudsman dapat melakukan mediasi, konsiliasi, dan ajudikasi khusus (dilaksanakan paling lambat 5 tahun sejak undang-undang ini diundangkan). Mekanisme pembayaran ganti rugi, diatur lebih lanjut dalam peraturan presiden. Masyarakat dapat menggugat penyelenggara atau pelaksana melalui peradilan tata usaha negara apabila pelayanan yang diberikan menimbulkan kerugian di bidang tata usaha negara. Masyarakat juga dapat mengajukan gugatan ke pengadilan terhadap penyelenggara yang melakukan perbuatan melawan hukum dalam penyelenggaraan pelayanan publik. Penyelenggara yang diduga melakukan tindak pidana dalam penyelenggaraan pelayanan publik, dapat diadukan oleh masyarakat kepada pihak yang berwenang. 
Penyelenggara atau Pelaksana yang melanggar ketentuan pada Pasal-pasal dan Ayat-ayat undang-undang ini, dikenai sanksi teguran tertulis, pembebasan dari jabatan, penurunan gaji sebesar satu kali kenaikan gaji berkala untuk paling lama 1 tahun, penurunan pangkat pada pangkat yang setingkat rendah untuk paling lama 1 tahun, pemberhentian dengan hormat tidak atas permintaan sendiri, pemberhentian tidak dengan hormat, pembekuan misi dan/atau izin yang diterbitkan oleh instansi pemerintah, dan/atau pencabutan izin yang diterbitkan oleh instansi pemerintah. Penyelenggara atau Pelaksana yang atas perbuatannya mengakibatkan timbulnya luka, cacat tetap, atau hilangnya nyawa bagi pihak lain, dikenai sanksi pidana sebagaimana diatur dalam peraturan perundang-undangan (tidak membebaskan dirinya membayar ganti rugi bagi korban dan besaran ganti rugi bagi korban ditetapkan berdasarkan putusan pengadilan).

Penyelenggara atau Pelaksana yang tidak melakukan kewajiban sebagaimana diatur pada Pasal 25 ayat (1) dan Pasal 28 ayat (1), dan ayat (4) yang atas perbuatan tersebut mengakibatkan kerugian negara, dikenai denda (yang ditetapkan berdasarkan putusan pengadilan). Sanksi bagi penyelenggara, dikenakan kepada pimpinan penyelenggara. Pimpinan penyelenggara dan/atau pelaksana yang dikenai sanksi dapat dilanjutkan pemrosesan perkara ke lembaga peradilan umum apabila penyelenggara melakukan perbuatan melawan hukum dan/atau penyelenggara melakukan tindak pidana.

Lima peraturan pemerintah dan satu peraturan presiden harus ditetapkan paling lambat 6 (enam) bulan sejak undang-undang ini ditetapkan. Enam dokumen tersebut adalah PP tentang Ruang Lingkup Pelayanan Publik, PP tentang Sistem Pelayanan Terpadu, PP tentang Standar Pelayanan Publik, PP tentang Proporsi Akses, dan PP tentang Tata Cara Pengikutsertaan Masyarakat dalam Penyelenggaraan Pelayanan Publik, serta Perpres tentang Ganti Rugi.

\section{SINERGI DAN APLIKASI EMPAT UNDANG-UNDANG DALAM PENERAPAN TEKNOLOGI}

Dari uraian substansi empat undangundang tersebut, terlihat keterkaitan tentang informasi, pelayanan publik, badan publik, penyelenggara pelayanan publik, sistem informasi, transparansi, akuntabilitas, peran serta masyarakat, demokrasi, dan upaya penciptaan tata pemerintahan yang baik (good governance). Menkominfo Muhammad Nuh menegaskan bahwa perbuatan hukum di dunia maya merupakan fenomena yang sangat mengkhawatirkan, mengingat tindakan carding, hacking, cracking, phising, booting, viruses, cybersquating, perjudian, penipuan, terorisme, dan penyebaran informasi destruktif telah menjadi bagian dari aktivitas pelaku kejahatan di dunia maya. UU ITE memberikan kepastian hukum dalam mengatasi perbuatan tersebut.

KIP mempunyai makna yang luas, meliputi badan publik eksekutif, legislatif, dan yudikatif. Dengan UU KIP, dibedakan informasi yang wajib disediakan secara berkala, wajib diumumkan secara serta merta, wajib tersedia setiap saat, dan informasi yang dikecualikan. UU KIP mngamanatkan agar pengelolaan informasi harus transparan, akuntabel, dan menegakkan prinsip good governance.

UU Ombudsman memberi kesempatan kepada setiap orang untuk melaporkan pelayanan publik yang tidak sesuai dengan undang-undang dan petunjuk pelaksanaannya. Penyelenggara dan pelaksana pelayanan publik harus mengubah mind-set dan cultural-set, karakter, jati diri, budaya kerja, etika, dan disiplin; serta tidak gagap dalam pemanfaatan teknologi informasi. Sejalan dengan itu, pemerintah wajib memberikan perhatian, antara lain pendanaan, dalam mendukung kelancaran pelayanan publik.

Tentang kelembagaan dan peningkatan peran Ombudsman, samakan pengertian tentang mediasi, konsiliasi, ajudikasi, dan ajudikasi khusus, sehingga tindak lanjut penanganan sengketa dan ganti rugi bisa diselesaikan dengan baik, ada kejelasan sanksi untuk memberikan efek jera, dan kejelasan siapa yang harus melakukan pembayaran ganti rugi. Tentang tata cara pengikut-sertaan masyarakat, perlu dicermati jenis pelayanan publik, siapa yang berpartisipasi, representasi, replikasi, pada tahap mana perlu partisipasi, dan apa bentuk partisipasi.

Permenpan Nomor 20 Tahun 2006 tentang Standar Pelayanan, bisa ditingkatkan menjadi materi PP Standar Pelayanan Publik. Bagaimana peran Depkeu dan DPRD dalam penetapan biaya dan tarif, bagaimana kontrak pelayanan atau maklumat pelayanan di samping standar pelayanan, pelibatan pemangku kepentingan (stakeholders), penggunaan bahasa yang sederhana dan mudah dimengerti, memerankan pihak ketiga sebagai fasilitator, batas waktu penetapan standar pelayanan, dan ketegasan standar pelayanan harus implementatif dan aplikatif.

Pelayanan terpadu harus dapat memudahkan pengguna layanan. Pelayanan berjenjang adalah pelayanan harus sama, yang berbeda dan berjenjang adalah pemberi pelayanannya, perubahan paradigma pelayanan publik, ruang diskresi, kejelasan tolok ukur 
pelayanan atau kejelasan unsur-unsur standar pelayanan, dan kejelasan pengertian masyarakat rentan. Pelayanan bagi masyarakat ekonomi lemah jangan sampai tergusur dengan adanya excellence of services atau pelayanan VIP dan segala hal tentang pelayanan publik harus mudah diketahui dan diakses.

Agar pelaksanaan empat undangundang dalam penerapan teknologi (difusi, inovasi, dan peningkatan daya saing), termasuk teknologi lingkungan dan teknologi pengelolaan air bersih berjalan lancar, maka perlu ditingkatkan kesiapan dan pemantapan pengumpulan data (identifikasi, inventarisasi), pengolahan data, pengelolaan sistem informasi, komputerisasi serta sarana dan prasarana teknologi informasi lainnya, penciptaan pelayanan serba cepat dan akurat, serta dilakukan upaya peningkatan peran serta masyarakat. Para penyelenggara dan pelaksana pelayanan publik dan badan publik hendaknya berusaha menegakkan tujuh asas penyelenggaraan negara yang bersih dan bebas dari KKN (kepastian hukum, tertib penyelenggaraan negara, kepentingan umum, keterbukaan, proporsionalitas, profesionalitas, dan akuntabilitas).

Pemahaman terhadap pengertian undang-undang ini perlu ditingkatkan dan disamakan, asas-asas harus ditegakkan, kelembagaan harus ditata dengan baik, kualitas SDM harus ditingkatkan, sistem, mekanisme dan prosedur kerja harus ditegakkan, sarana dan prasarana teknologi informasi harus memadai, dan sanksi harus dipahami (sanksi administratif dan sanksi pidana). Sejalan dengan itu, internalisasi dan sosialisasi undang-undang harus lebih diintensifkan.

\section{SISTEM INFORMASI TEKNOLOGI PENGELOLAAN AIR BERSIH DAN LIMBAH CAIR}

BPPT adalah lembaga yang melakukan penerapan dan pengembangan teknologi yang berdomisili di Jakarta dan Serpong. Hal ini menyebabkan keterbatasan dalam penyebaran paket-paket teknologi ke daerah-daerah lainnya, sehingga masyarakat pada umumnya tidak mengetahui apa saja yang telah dilakukan BPPT serta dirasakan masih sulitnya memperoleh informasi teknologi yang mereka butuhkan.

Sistem informasi teknologi pengelolaan air bersih dan limbah cair (SITPABLC) adalah sistem informasi yang bertujuan memberikan pelayanan informasi dan teknologi untuk mempercepat mencari, memperoleh / mengakses, mengadopsi/memanfaatkan dan memasyarakatkan teknologi yang telah dikaji dan dikembangkan oleh BPPT. Situs SITPABLC dapat diakses di www.kelair.bppt.go.id

SITPABLC mempunyai lingkup kegiatan sebagai berikut :

1. Pemanfaatan, pengembangan dan penguasaan teknologi pengelolaan sumber air, meliputi air tanah, air permukaan dan daerah aliran sungai.

2. Pemanfaatan, pengembangan dan peguasaan teknologi pengolahan air bersih dan air limbah, untuk daerah perkotaan, pedesaaan dan air untuk keperluan industri.

3. Pemanfaatan, pengembangan dan penguasaan teknologi pengolahan limbah cair untuk rumah tangga, perkantoran, rumah sakit, industri dan sektor jasa lainnya di perkotaan dan pedesaan.

4. Pelayanan jasa dan konsultasi teknologi di bidang pengelolaan sumberdaya air, teknologi pengolahan air bersih dan limbah cair.

Beberapa produk paket teknologi (patek) dan pelayanan serta publikasi yang telah dihasilkan, antara lain(10) :

1. Paket Teknologi Pengolahan Air Bersi dan Air Minum

- Paket Teknologi Filter Air Untuk Menghilangkan Zat Besi (Fe) Dan Mangan (Mn) - FILTRA.

- Paket Teknologi Pengolahan Air Sumur Siap Minum - ARSINUM.

- Paket Teknologi Pengolahan Air Sederhana Dengan Sistem Saringan Pasir Lambat "Up-Flow" - SARPALAM.

- Paket Teknologi Pengolahan Air Gambut Sistem Batch-TP2AS.

- Paket Teknologi Pengolahan Air Gambut Payau/Asin Sistem Kontinyu-ROBIOFIL.

- Paket Teknologi Pengolahan Air Payau/Asin Dengan Sistem Osmosis Balik (RO) Statisioner - ROSTATIS.

- Paket Teknologi Pengolahan Air Payau/Asin Dengan Sistem Osmosis Balik Mobile - ROMOBIL.

- Paket Teknologi Pengolahan Air Bersih dengan Sistem Ultrafiltrasi - ULTRAFIL.

- Paket Teknologi Pengolahan Air Minum dengan Sistem Biofiltrasi, Ultrafiltrasi \& Reverse Osmosis - ROBIOULTRAFIL.

- Paket Teknologi Pengolahan Air Minum dengan Sistem Ultrafiltrasi \& Reverse Osmosis - ROULTRAFIL.

- Paket Teknologi Pengolahan Air Re-use Limbah Cair dengan Sistem Reverse Osmosis - ROREUSE.

2. Paket Teknologi Pengolahan Air Limbah

- Paket Teknologi Pengolahan Limbah Cair Rumah Sakit Sistem Biofilter Aerob- 
Anaerob - LIMBRS.

- Paket Teknologi Pengolahan Limbah Cair Domestik Sistem Individu/Komunal Biofilter Aerob-Anaerob - LIMBRT.

- Paket Teknologi Pengolahan Limbah Cair Industri (Makanan, Pelapisan Logam, Tekstil Pencucian Jeans, Rumah Potong Hewan, Amonia, Kertas, Otomotif, dll.).

- Paket Teknologi Pengelolaan Limbah Cair B3.

3. Paket Teknologi Pengembangan Perangkat

Lunak

- Sistem Informasi Sumber Daya Air SISDA.

- Sistem Informasi Teknologi Pengolahan Air (Lingkungan) - SITPA.

- Sistem Informasi Manajeman Lingkungan - SIMLING.

- Sistem Informasi Pengelolaan Drainase Kota - DRAINASE.

- Sistem Online Monitoring Kualitas Air ONLIMO.

- Database Sumber Daya Air - DBSDA.

- Database Kualitas Air - DBKwaair.

- Pengelolaan Air Tanah Dengan Sistem Informasi Geografis - PATGIS.

- Pemetaan Potensi Air Tanah Dengan Geolistrik - GEOLISTRIK.

4. Paket Teknologi Pelatihan Profesional

- Teknologi Pengelolaan Air Bersih.

- Teknologi Pengolahan Limbah Cair.

- Pengelolaan Limbah B3.

- Sistem Informasi Geografis Untuk Pengelolaan Air Tanah.

- Pengembangan Sistem Informasi Sumber Daya Air.

- Pengembangan Jaringan Komputer Menggunakan Open Source.

5. Jasa dan Pelayanan Publik

- Disain dan konstruksi sistem teknologi pengelolaan air bersih.

- Disain dan konstruksi sistem teknologi pengolahan limbah cair industri.

- Disain dan konstruksi paket instalasi pengolahan air limbah rumah sakit

- Disain dan konstruksi teknologi desalinasi untuk pengolahan air asin/payau menjadi air tawar atau air siap minum.

- Merancang unit pengolahan air minum sesuai dengan air baku dan kondisi kualitas setempat.

- Konsultasi bidang Pengelolaan Air Tanah Dataran Pantai.

- Konsultasi bidang Sistem Informasi Geografi (GIS) khususnya untuk bidang teknologi pengolahan dan pengelolaan sumber daya air.
- Konsultasi bidang Pengelolaan Sumber Daya Air.

- Pengembangan database lingkungan.

- Pengembangan database sumber daya air.

- Pengembangan database kualitas air.

- Eksploitasi dan eksplorasi air tanah.

- Pendidikan dan latihan bidang teknologi pengolahan air bersih dan limbah cair.

- Pendidikan dan latihan di bidang pengelolaan air tanah menggunakan sistem informasi geografis.

- Pendidikan dan latihan di bidang pengelolaan dan pengembangan sistem informasi sumber daya air.

6. Publikasi Buku, Jurnal dan CD-ROM

- Pelayanan Informasi Elektronik Untuk Paket Teknologi Pengolahan Air.

- Perancangan Sistem Basis Data Sumber Daya Air.

- Kesehatan Masyarakat dan Teknologi Peningkatan Kualitas Air.

- Kualitas Air Minum dan Dampaknya Terhadap Kesehatan.

- Aplikasi Biofilter Untuk Pengolahan Air Limbah Industri Kecil Tekstil.

- Uji Performance Pengolahan Air Limbah Rumah Sakit Dengan Proses Biofilter Tercelup.

- Sistem Pengolahan Limbah B3 di Indonesia.

- Himpunan Peraturan Perundangan Pengelolaan Limbah B3.

- Teknologi Pengolahan Limbah Cair Industri.

- Jurnal Air Indonesia.

- Jurnal Teknologi Lingkungan.

- CD-ROM Cara Pengolahan Air Sumur Untuk Kebutuhan Air Minum.

- CD-ROM Teknologi Pengolahan Air Bersih Dengan Proses Saringan Pasir Lambat Up Flow.

- CD-ROM Pengolahan Air Asin atau Payau Dengan Sistem Osmosis Balik.

- CD-ROM Pengolahan Limbah Rumah Tangga Semi Komunal Kombinasi Biofilter Anaerob-Aerob.

- CD-ROM Teknologi Pengolahan Limbah Rumah Sakit Dengan Sistem Biofilter Anaerob-Aerob.

- CD-ROM Teknologi Pengkajian Sistem Pengelolaan Air Tanah Di Cekungan Semarang.

- CD-ROM Jurnal Teknologi Lingkungan 2000, 2001, 2002, 2003.

- CD-ROM Himpunan Peraturan Bidang Lingkungan. 
Paket-paket teknologi tersebut secara lengkap baik merupakan foto/gambar, maupun spesifikasi dan cara pembuatan, dapat diakses kapanpun dan dimanapun. Pelayanan dan konsultasi dapat dilakukan melalui e-mail, telepon atau fasilitas lainnya (Gambar 1, 2, 3, 4 \& 5).

Jurnal Teknologi Lingkungan dan Jurnal Air Indonesia, materi-materi hasil seminar, pelatihan dan perundang-undangan di bidang lingkungan dapat diunduh (download) secara mudah dan relatif cepat (Gambar 6 \& 7).

Pameran dan pelatihan secara periodik dilaksanakan untuk memasyarakatkan hasil-hasil kajian dan pengembangan teknologi selama ini. Selain itu melalui rubrik teknologi di layar kaca dan di radio, serta di media cetak pemasyarakatan teknologi pengolahan air bersih dan limbah cair juga dilakukan.

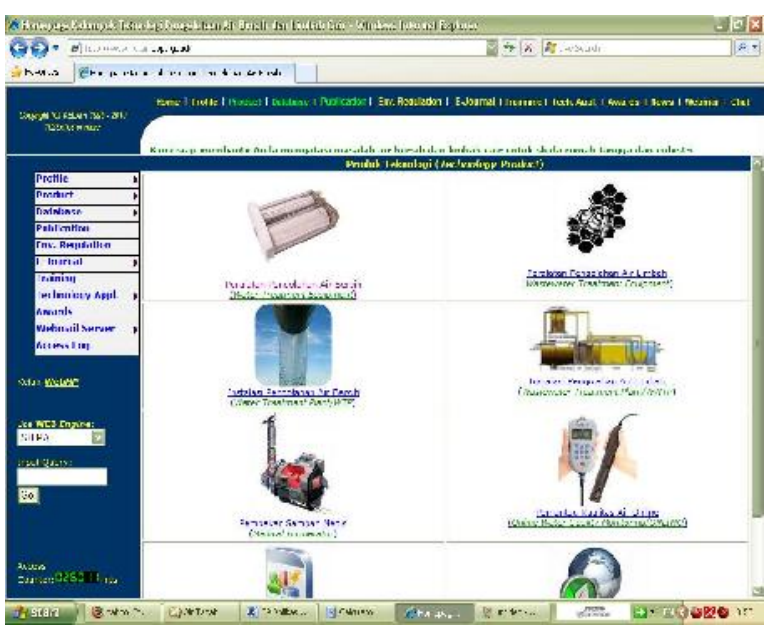

Gambar 1. Pemilihan produk paket teknologi

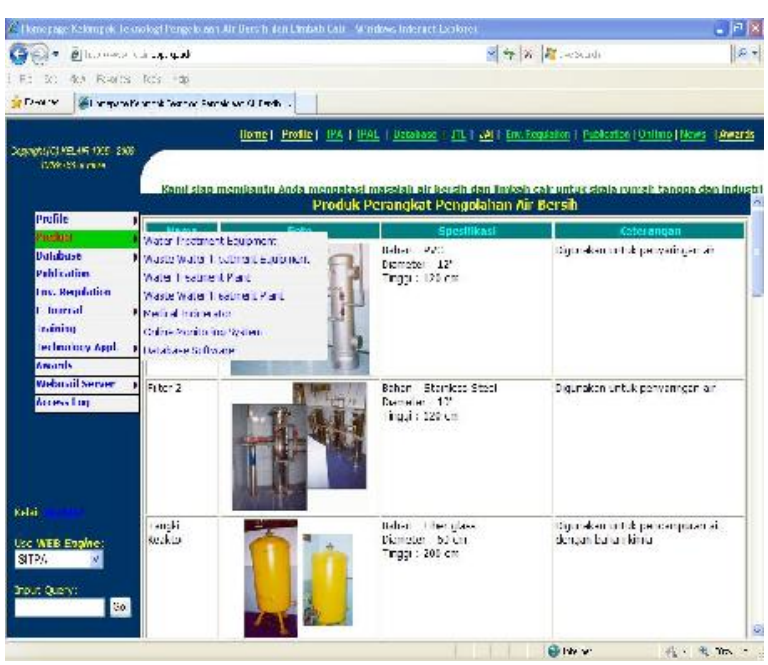

Gambar 2. Paket-paket teknologi pengolahan air bersih

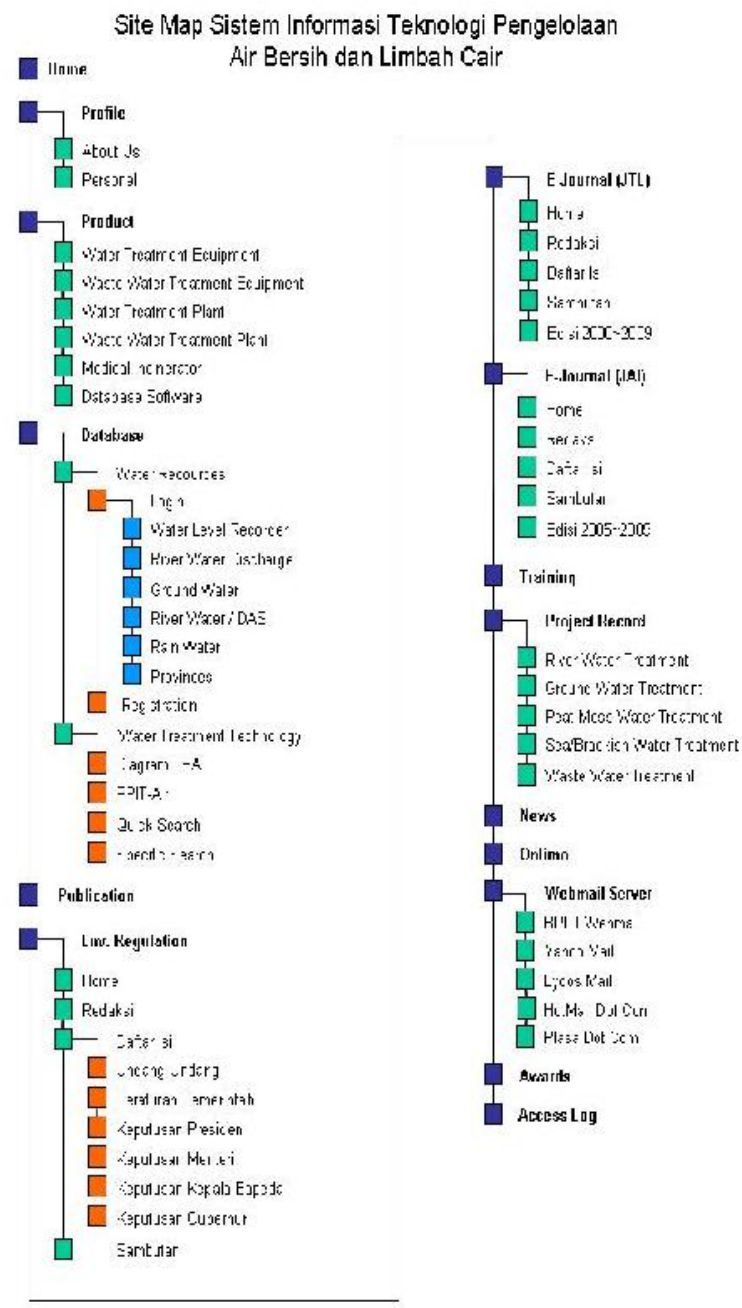

Gambar 3. Site map sistem informasi teknologi pengelolaan air bersih dan limbah cair

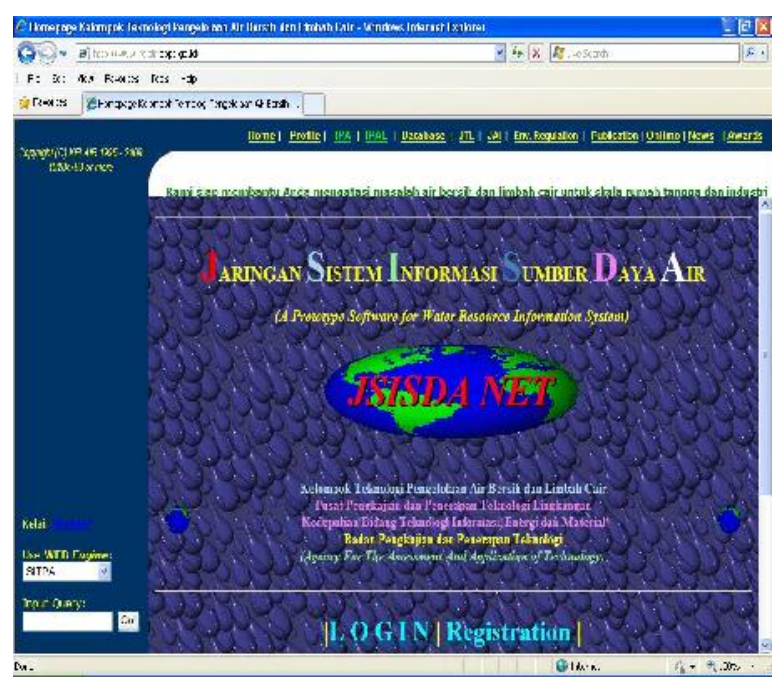

Gambar 4. Jaringan sistem informasi sumber daya air 


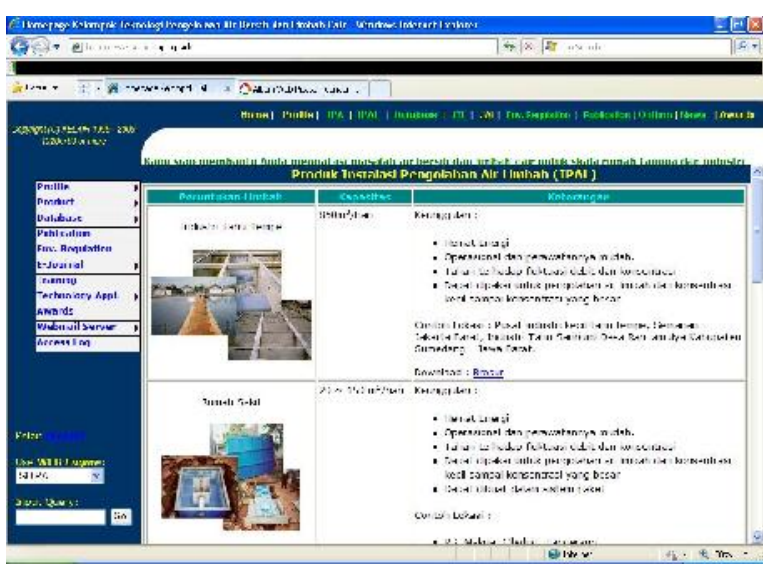

Gambar 5. Paket-paket teknologi pengolahan limbah cair

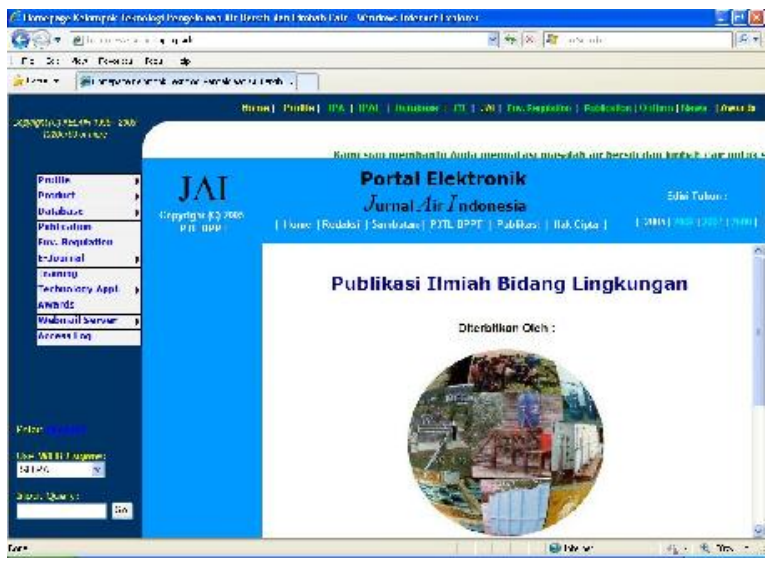

Gambar 6. Jurnal Air Indonesia edisi tahun 2000 s.d. 2008

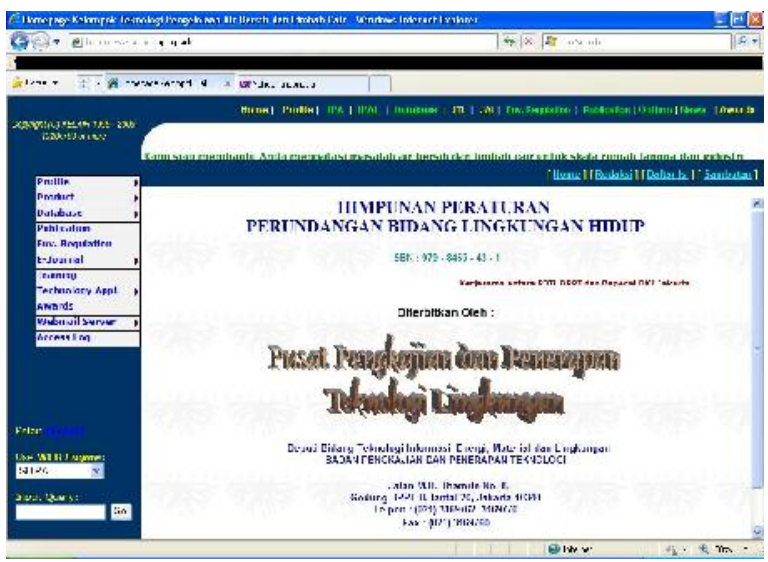

Gambar 7. Kumpulan Perundangan di bidang lingkungan (UU-PP-Kepmen-SK.Gub)

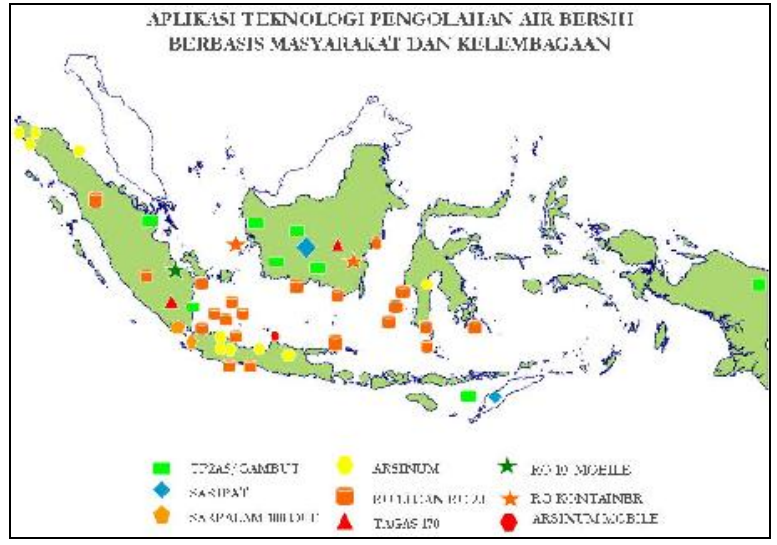

Gambar 8. Lokasi aplikasi berbagai jenis teknologi pengolahan air bersih/minum di seluruh Indonesia

\section{KESIMPULAN}

Beberapa kesimpulan dari tulisan di atas antara lain :

1. Substansi empat undang-undang tersebut mempunyai keterkaitan tentang informasi, pelayanan publik, badan publik, penyelenggara pelayanan publik, sistem informasi, transparansi, akuntabilitas, peran serta masyarakat, demokrasi, dan upaya penciptaan tata pemerintahan yang baik (good governance).

2. Transparansi, akuntabilitas, dan partisipasi, merupakan unsur penting good governance, yang ditonjolkan dalam UU ITE, UU KIP, UU Ombudsman, dan UU Pelayanan Publik. Penyelenggaran yang transparan, mengakibatkan kebohongan sulit disembunyikan dan keterbukaan akan memudahkan penegakan aturan dan keadilan. Perubahan mind-set dan cultural-set, disiplin, budaya kerja, dan etika para penyelenggara dan pelaksana pelayanan publik dan badan publik mutlak diperlukan agar tercipta pelayanan publik prima, berkualitas, cepat, tepat, dan akurat, bermoral dan bertanggungjawab.

3. Dengan penerapan empat undang-undang ini kita berharap agar tata kelola pemerintahan yang baik (good public governance) dan tata kelola perusahaan yang baik (good corporate governance) segera terwujud.

4. Salah satu usaha yang telah dilakukan BPPT dalam memenuhi apa yang disiratkan oleh empat undang-undang tersebut adalah dengan membangun Sistem Informasi Teknologi Pengelolaan Air Bersih dan Limbah Cair (SITPABLC). 
5. Paket-paket teknologi pengolahan air tersebut dikaji dan dikembangkan untuk mengatasi permasalahan dalam memenuhi kebutuhan masyarakat akan air bersih dan air minum. Teknologi ini disesuaikan dengan kondisi permasalahan sumber air baku yang ada di setiap daerah.

6. Paket-paket teknologi pengolahan limbah cair dikaji dan dikembangkan untuk mengatasi dan menurunkan pencemaran lingkungan, baik dari limbah cair domestik maupun dari limbah cair industri.

7. Pelayanan informasi dan konsultasi untuk mengatasi permasalahan pengelolaan air bersih dan limbah cair bagi masyarakat dapat secara mudah diperoleh melalui SITPABLC.

\section{DAFTAR PUSTAKA}

1. BPP Teknologi, Situs Resmi BPPT Http://www.bppt.go.id/, 2010

2. Suprawoto, Kepala Badan Informasi Publik, Depkominfo, "Sosialisasi di KPK: UU 14/2008 tentang KIP dan UU 11/2008 tentang ITE", Jakarta, Maret 2008.

3. Freddy H.Tolung, Depkominfo, "Sosialisasi UU 14/2008", Pertemuan Bakohumas seSumatera, Palembang, 26-27 Mei 2008.

4. Komarudin, "Implementasi UU 14/2008 tentang KIP di lingkungan Departemen Kesehatan", Pertemuan Nasional Humas Kesehatan di Surabaya, 20 Oktober 2008 dan Diklat Puskomlik Departemen Kesehatan di Bandung, 15 November 2008.

5. Komarudin, "RPP Standar Pelayanan Publik Tindak Lanjut UU 25/2009 tentang Pelayanan Publik". Makalah binteknas pejabat pemerintah daerah, Denpasar, 7 Desember 2009.

6. Undang-undang Nomor 11 Tahun 2008 tentang Informasi dan Transaksi Elektronik.

7. Undang-undang Nomor 14 Tahun 2008 tentang Keterbukaan Informasi Publik.

8. Undang-undang Nomor 25 Tahun 2009 tentang Ombudsman Republik Indonesia.

9. Undang-undang Nomor 25 Tahun 2009 tentang Pelayanan Publik.

10. Kelompok Air BPPT, Situs Resmi Kelompok Fungsional Teknologi Pengelolaan Air Bersih dan Limbah Cair Http://www.kelair.bppt.go.id/, 2010 